\title{
Involvement of nitric oxide donor compounds in the bactericidal activity of human neutrophils in vitro
}

\author{
Correspondence \\ Magdalena Klink \\ mklink@cmiwpan.lodz.pl
}

Received 20 May 2002

Accepted 21 November 2002

\author{
Magdalena Klink, ${ }^{1}$ Maciej Cedzyński, ${ }^{1}$ Anna St Świerzko, ${ }^{1}$ \\ Henryk Tchórzewski ${ }^{1,2}$ and Zofia Sułowska ${ }^{1}$ \\ ${ }^{1}$ Microbiology and Virology Centre, Polish Academy of Sciences, 93-232 Lodz, Lodowa 106, Poland \\ ${ }^{2}$ Department of Clinical Immunology, Institute of Polish Mothers' Memorial Hospital, 93-338 Lodz, \\ Rzgowska 281/289, Poland
}

\begin{abstract}
The bactericidal activity of human neutrophils against extracellular and facultatively intracellular bacteria was studied in the presence of the nitric oxide (NO) donors sodium nitroprusside (SNP) and 3-morpholinosydnonimine (SIN-1), a molsidomine metabolite. SNP and molsidomine are drugs commonly used as nitrovasodilators in coronary heart disease. It is demonstrated here that the NO donor compounds themselves did not affect the viability and survival of the bacterial strains tested. Neither SNP nor SIN-1 had any effect on the process of bacteria ingestion. In contrast, NO donors enhanced the ability of neutrophils to kill Escherichia coli, Proteus vulgaris and Salmonella Anatum. However, strains differed in their susceptibility to SNP- and SIN-1-mediated killing by neutrophils. Removal of the superoxide anion reduced the bactericidal activity of SNP- and SIN-1-treated neutrophils against $E$. coli and $S$. Anatum. This suggests that the NO derivatives formed in the reaction of NO generated from donors with the reactive oxygen species released by phagocytosed neutrophils potentiate the bactericidal activity of human neutrophils in vitro. The above original observation discussed here suggests clinical significance for the treatment of patients with nitrovasodilators in the course of coronary heart disease therapy.
\end{abstract}

\section{INTRODUCTION}

Neutrophils play a key role in host defence against a wide variety of micro-organisms. They are able to kill microorganisms by two distinct mechanisms, one of which is oxygen dependent, while the other is oxygen independent (Verhoef \& Visser, 1993). The principal bactericidal agents derived from neutrophils are reactive oxygen species (ROS) such as the superoxide anion $\left(\mathrm{O}_{2}^{-}\right)$and hydroxyl radical $\left(\mathrm{OH}^{-}\right)$as well as non-radical species such as hydrogen peroxide $\left(\mathrm{H}_{2} \mathrm{O}_{2}\right)$ (Umeki, 1994; Saran et al., 1999). They are produced during a complex series of reactions named the 'respiratory burst'. The superoxide anion is converted into $\mathrm{H}_{2} \mathrm{O}_{2}$ spontaneously and/or via the action of superoxide dismutase (SOD). The interaction of $\mathrm{O}_{2}^{-}$with $\mathrm{H}_{2} \mathrm{O}_{2}$ leads to the formation of the hydroxyl radical, which is a strongly bactericidal agent. In the reaction of $\mathrm{H}_{2} \mathrm{O}_{2}$ with $\mathrm{Cl}^{-}$, catalysed by myeloperoxidase (MPO), highly toxic $\mathrm{HOCl}$ is formed (Babior, 1999; Jones et al., 2000).

In addition to the ROS, the nitric oxide molecule (NO) is considered an antimicrobial agent against various species of bacteria, viruses, yeasts and parasites (De Groote \& Fang,

Abbreviations: $\mathrm{CL}$, chemiluminescence; $\mathrm{RNI}$, reactive nitrogen intermediate; ROS, reactive oxygen species; SIN-1, 3-morpholinosydnonimine; SNP, sodium nitroprusside.
1995; Fang, 1997). The mechanism by which NO kills bacteria is controversial. Several reports have indicated that NO supports the toxicity of ROS by interaction with the superoxide anion to produce the highly reactive peroxynitrite anion $\left(\mathrm{ONOO}^{-}\right)$(Fang, 1997; Zhu et al., 1992), which is subsequently decomposed into potent antimicrobial reactive nitrogen intermediates (RNIs) (Fang, 1997; Bogdan et al., 2000; Squadrito \& Pryor, 1998). Nitrite, a major end product of NO metabolism, can be converted into nitryl chloride $\left(\mathrm{NO}_{2} \mathrm{Cl}\right)$ and nitrogen dioxide $\left(\mathrm{NO}_{2}\right)$ through an MPOdependent pathway (Dahlgren \& Karlsson, 1999; Eiserich et al., 1998). The formation of $\mathrm{ONOO}^{-}, \mathrm{NO}_{2} \mathrm{Cl}$ and $\mathrm{NO}_{2}$ in neutrophils may represent one of the important mechanisms of host defence (Eiserich et al., 1998).

NO donor compounds such as sodium nitroprusside (SNP) or 3-morpholinosydnonimine (SIN-1), a molsidomine metabolite, are drugs commonly used as nitrovasodilators in coronary heart disease (Yamamoto \& Bing, 2000; Feelisch, 1991). In addition to their effect on vascular smooth muscle cells, NO donors affect circulating white blood cells by inhibiting adhesion and aggregation of neutrophils (Armstrong, 2001). In this study, we have investigated the effect of exogenously administrated SNP and SIN-1 on the bactericidal capacity of human neutrophils in vitro. 


\section{METHODS}

Chemical reagents. Polymorphprep was obtained from Nycomed. RPMI 1640 medium, Hanks' balanced salt solution (HBSS), sodium nitrite, sulfanilamide, naphthylethylenediamine dihydrochloride, phosphoric acid, 3-[4,5-dimethylthiazol-2-yl]-2,3-diphenyltetrazolium bromide (MTT), SNP, SIN-1, catalase (CAT), SOD, FITC, BSA, phorbol 12-myristate 13-acetate (PMA) and saponin were purchased from Sigma. Luminol was from Serva. Calf serum was obtained from Gibco-BRL. McFarland Standard and CLED agar were from bioMérieux. PBS was purchased from BIOMED-Lublin.

Isolation of neutrophils. Blood samples were drawn directly into heparinized tubes $\left(5 \mathrm{U} \mathrm{ml}^{-1}\right)$ from healthy volunteers. The $5 \mathrm{ml}$ blood samples were layered onto $3 \mathrm{ml}$ Polymorphprep and centrifuged at $450-500 \mathrm{~g}$ for $30 \mathrm{~min}$. The top band, containing mononuclear cells, was removed, while the lower one, containing polymorphonuclear cells, was collected. The neutrophils were washed twice with PBS. Neutrophil viability $(>95 \%)$ and cell purity $(>95 \%)$ were assessed by Trypan blue exclusion and May-Grünwald-Giemsa staining, respectively. The Regional Commission approved the protocol of these studies for Ethics in Research.

Bacteria. Escherichia coli strain LI1 was from the collection of the Institute of Microbiology and Immunology, University of Lodz, Poland. Proteus vulgaris PrK48/57 was obtained from the Czech National Collection of Type Cultures. Salmonella enterica serotype Anatum (S. Anatum) KOS78 was a kind gift of Professor R. Glośnicka, Institute of Maritime and Tropical Medicine, Gdynia, Poland. Bacteria were grown in tryptic soy agar for $18 \mathrm{~h}$ at $37^{\circ} \mathrm{C}$ and harvested and washed three times with PBS by centrifugation $\left(2500 \mathrm{~g}, 15 \mathrm{~min}, 4{ }^{\circ} \mathrm{C}\right)$. The bacterial cell density was adjusted spectrophotometrically according to McFarland Standard (550 nm, ELISA reader Multiscan RC, Labsystem) to $1.5 \times 10^{9}$ cells $\mathrm{ml}^{-1}$.

Measurement of the generation of NO from NO donor compounds. The amount of NO generated from SNP and SIN-1 in our systems was determined. Neutrophils $\left(5 \times 10^{5}\right.$ cells per well $)$ were mixed with bacteria $\left(5 \times 10^{6}\right.$ cells per well $)$ in the presence of SNP $(10$ $1000 \mu \mathrm{M})$ or SIN-1 $(10-1000 \mu \mathrm{M})$ in RPMI 1640 medium for 5 or $60 \mathrm{~min}$ at $37^{\circ} \mathrm{C}$. In some experiments, SNP $(10-1000 \mu \mathrm{M})$ or SIN-1 $(10-1000 \mu \mathrm{M})$ was added to RPMI medium alone (cell-free system) for 5 min at $37^{\circ} \mathrm{C}$. The generation of $\mathrm{NO}$ was measured by quantification of nitrite $\left(\mathrm{NO}_{2}^{-}\right)$, a stable metabolite of $\mathrm{NO}$, using the Griess reagent $(1 \%$ sulfanilamide mixed with $0.1 \%$ naphthylethylenediamine dihydrochloride in $5 \%$ phosphoric acid). Griess reagent (100 $\mu \mathrm{l})$ was added to an equal volume of culture supernatant and the reaction mixture was incubated for $10 \mathrm{~min}$ at room temperature. The absorbance was determined at $550 \mathrm{~nm}$ in an ELISA reader (Multiscan RC). Nitrite concentrations were then calculated using a standard curve generated with a serial dilution of sodium nitrite from 0.5 to $100 \mu \mathrm{M}$ (Green et al., 1982).

Effect of NO donors on bacterial survival. SNP (100 or $1000 \mu \mathrm{M})$ or SIN-1 (100 or $1000 \mu \mathrm{M})$ was added to RPMI 1640 culture medium in a 96 well plate for 5 min to initiate NO generation. Bacteria $\left(5 \times 10^{6}\right.$ cells per well) were then added to RPMI 1640 medium with or without NO donors. The reaction mixtures were incubated for $1 \mathrm{~h}$ at $37^{\circ} \mathrm{C}$. MTT solution $\left(0.5 \mathrm{mg} \mathrm{ml}^{-1}\right)$ was then added to the bacteria and the plate was incubated for another hour at $37^{\circ} \mathrm{C}$. Live bacteria converted the yellow tetrazolium salt of MTT to the dark-blue formazan product. Formazan was solubilized with 2-propanol ( $200 \mu \mathrm{l}$ per well) and the absorbance at $590 \mathrm{~nm}$ was measured in an ELISA reader (Multiscan RC). The absorption of formazan is directly related to the number of viable bacteria.
Labelling of bacteria. Bacteria $\left(1 \times 10^{9}\right.$ cells $\left.\mathrm{ml}^{-1}\right)$ in PBS were heated for $1 \mathrm{~h}$ at $60^{\circ} \mathrm{C}$ and then washed twice with PBS. Heat-killed bacteria were labelled with FITC $\left(100 \mu \mathrm{g} \mathrm{ml}^{-1}\right)$ in sodium carbonate buffer (SCB: $35 \mathrm{mM} \mathrm{NaHCO}, 15 \mathrm{mM} \mathrm{Na}_{2} \mathrm{CO}_{3}, \mathrm{pH} 9 \cdot 6$ ) for $18 \mathrm{~h}$ at room temperature with gentle agitation. They were then washed three times with PBS and resuspended in SCB containing $4 \%$ BSA and stored for $15 \mathrm{~min}$ at room temperature to bind unconjugated FITC to BSA. The cells were then washed once with SCB $+4 \%$ BSA and once with PBS. Finally, the bacteria were resuspended in RPMI 1640 medium supplemented with $20 \%$ calf serum at a concentration of $1 \times 10^{9}$ cells ml $^{-1}$ and stored at $4{ }^{\circ} \mathrm{C}$ (Chmiela et al., 1998).

Phagocytosis assay. Neutrophils and FITC-labelled bacteria were resuspended in RPMI 1640 medium supplemented with $20 \%$ pooled human serum at respective concentrations of $1 \times 10^{6}$ and $1 \times 10^{8}$ cells $\mathrm{ml}^{-1}$. Equal volumes $(100 \mu \mathrm{l})$ of the neutrophil suspension $\left(1 \times 10^{5}\right.$ cells $)$ and the FITC-labelled bacteria suspension $\left(1 \times 10^{7}\right.$ cells $)$ were mixed in the absence or presence of NO donors $(100$ and $1000 \mu \mathrm{M})$ in a 96 well plate. The plate was incubated for $1 \mathrm{~h}$ at $37^{\circ} \mathrm{C}$ with $5 \% \mathrm{CO}_{2}$. After that time, the plate was centrifuged $(5 \mathrm{~min}, 300 \mathrm{~g}$ ) and medium was removed. Extracellular fluorescence was quenched with $100 \mu \mathrm{l}$ $0 \cdot 1 \%$ Trypan blue in PBS per well. The plate was placed in a Fluoroscan Ascent FL fluorometer (Labsystem) and the intensity of fluorescence was determined in relative fluorescence units (RFU) at $485 \mathrm{~nm}$ excitation and $530 \mathrm{~nm}$ emission wavelengths. The intensity of fluorescence is directly proportional to the number of bacteria ingested. In each experiment, a standard curve of FITC-labelled bacteria was prepared (Chmiela et al., 1998).

\section{Neutrophil bactericidal activity assays}

Bacteria $\left(1 \times 10^{8} \mathrm{ml}^{-1}\right)$ were opsonized with $20 \%$ pooled human serum in RPMI 1640 medium $\left(20 \mathrm{~min}, 37^{\circ} \mathrm{C}\right)$. The bacteria were then washed with RPMI 1640 medium by centrifugation $(2500 \mathrm{~g}, 15 \mathrm{~min}$, $4{ }^{\circ} \mathrm{C}$ ). The neutrophils and bacteria were resuspended in RPMI 1640 medium supplemented with $5 \%$ calf serum. The MTT colorimetric microassay and counting of bacterial colonies were employed for quantification of the bactericidal activity of neutrophils.

MTT colorimetric microassay. SNP (100 or $1000 \mu \mathrm{M})$ or SIN-1 (100 or $1000 \mu \mathrm{M}$ ) was added to RPMI 1640 culture medium in a 96 well plate for 5 min to initiate NO generation. Neutrophils $\left(5 \times 10^{5}\right.$ cells per well $)$, cells of E. coli, P. vulgaris or $S$. Anatum $\left(5 \times 10^{6}\right.$ cells per well $)$ and/or CAT $\left(1000 \mathrm{U} \mathrm{ml}^{-1}\right)$ and/or SOD $\left(100 \mathrm{U} \mathrm{ml}^{-1}\right)$ were then added to RPMI 1640 medium with or without NO donors. The reaction mixtures were incubated for $1 \mathrm{~h}$ at $37^{\circ} \mathrm{C}$ (OD sample). Control samples contained (i) neutrophils in culture medium (OD $90 \%$ killing) or (ii) bacteria in culture medium (OD $0 \%$ killing). Neutrophils were lysed by adding saponin $(0.05 \%)$ for $20 \mathrm{~min}$ at room temperature. MTT solution and 2-propanol were then added as described above. In each experiment, standard curves of bactericidal activity were prepared. Bacteria $\left(5 \times 10^{6}\right.$ cells $)$ were diluted in RPMI medium with $5 \%$ calf serum to $1 \times 10^{6}$ and $0.5 \times 10^{6}$ cells per well, corresponding to 50 and $100 \%$ reductions in the number of cells, and incubated for $1 \mathrm{~h}$ at $37^{\circ} \mathrm{C}$. Saponin, MTT solution and 2-propanol were then added as described above. The $A_{590}$ was then measured using an ELISA reader. The limit of error was calculated as $10 \%$ and values obtained were reduced by $10 \%$. An OD corresponding to $5 \times 10^{6}$ was determined as $0 \%$ of bacteria killed. The OD of lysed (saponin-treated) neutrophils in the medium was calculated as $90 \%$ bacteria killed. The percentage of bacteria killed by neutrophils was calculated from the formula: $1-(\mathrm{OD}$ sample-OD $90 \%$ killing $) /($ OD $0 \%$ killing-OD $90 \%$ killing) $\times 90 \%$ (Stevens \& Olsen, 1993).

Colony counting (c.f.u. assay). SNP $(1000 \mu \mathrm{M})$ or SIN-1 $(1000 \mu \mathrm{M})$ was added to RPMI 1640 culture medium for $5 \mathrm{~min}$ to initiate NO generation. Neutrophils $\left(5 \times 10^{6}\right.$ cells $)$ and bacteria $\left(5 \times 10^{7}\right.$ cells $)$ were then added to RPMI 1640 medium with or without NO donors. 
The reaction mixtures were incubated for $1 \mathrm{~h}$ at $37^{\circ} \mathrm{C}$. Control samples contained bacteria only $\left(5 \times 10^{7}\right.$ cells $)$ with or without NO donors. After $1 \mathrm{~h}$ of incubation, the neutrophils were lysed by adding saponin $(0.05 \%)$ for $20 \mathrm{~min}$ at room temperature. All samples were serially diluted and $0.1 \mathrm{ml}$ aliquots were plated in triplicate on CLED agar plates. The agar plates were incubated overnight at $37^{\circ} \mathrm{C}$. Colonies were then counted and the number of colony-forming units (c.f.u.) was recorded. The percentage of bacteria killed by neutrophils was calculated from the formula: $1-$ (c.f.u. neutrophils + bacteria/c.f.u. bacteria) $\times 100 \%$.

Chemiluminescence (CL) assay. CL was measured in a 96 well plate with a Fluoroscan Ascent FL fluorometer. Neutrophils $\left(1 \times 10^{5}\right.$ cells per well in HBSS) were distributed into the 96 well plate and were untreated or treated with SNP or SIN-1 at concentrations of 100 or $1000 \mu \mathrm{M}$ or with $0 \cdot 1 \mu \mathrm{g}$ PMA for $1-2 \mathrm{~min}$. Luminol $\left(10^{-5} \mathrm{M}\right)$ was then added to the wells to enhance CL. The CL reading for all experiments was recorded for $30 \mathrm{~min}$ at $2 \mathrm{~min}$ intervals. The $\mathrm{CL}$ intensity was given in relative light units (RLU). The data were expressed as the area under the curve of CL versus time (RLU total).

Statistical analysis. Data are presented as means \pm SD. Statistical analysis was performed with Wilcoxon's signed rank test. Statistical significance was defined as $P \leqslant 0.05$.

\section{RESULTS}

\section{Generation of nitrite from NO donors}

In a preliminary study, we checked the generation of nitrite from SNP and SIN-1 in RPMI medium in the absence of neutrophils and bacteria (cell-free medium). We found that, after 5 min incubation, SNP and SIN-1 respectively led to an increase in nitrite from $0 \pm 0$ to $4 \cdot 3 \pm 4 \cdot 4 \mu \mathrm{M}$ and from $1 \cdot 1 \pm 0 \cdot 3$ to $25 \cdot 0 \pm 9 \cdot 2 \mu \mathrm{M}$. On the basis of these data, a 5 min pre-incubation time of NO donors in RPMI medium was considered sufficient to initiate nitrite generation and was used in subsequent experiments.

Fig. 1 shows that, in the presence of neutrophils and bacteria, SNP and SIN-1 respectively led to an increase in nitrite from $0 \cdot 2 \pm 0 \cdot 2$ to $16 \cdot 5 \pm 0 \cdot 6 \mu \mathrm{M}$ and from $0 \cdot 6 \pm 0 \cdot 1$ to $27 \cdot 4 \pm$ $1.8 \mu \mathrm{M}$ during the first $5 \mathrm{~min}$ and from $5.4 \pm 1.3$ to $27 \cdot 4 \pm 0.7 \mu \mathrm{M}$ and from $5 \cdot 0 \pm 0.5$ to $153 \cdot 8 \pm 22 \cdot 3 \mu \mathrm{M}$, respectively, after $60 \mathrm{~min}$ incubation. SNP and SIN-1 generated comparable amounts of nitrite during a $5 \mathrm{~min}$ incubation. In contrast, the amount of nitrite generated from SIN-1 after 60 min was statistically greater than from SNP $(P \leqslant 0 \cdot 04)$. On the basis of these data, NO donor concentrations of 100 and $1000 \mu \mathrm{M}$ were considered sufficient and were used in subsequent experiments.

\section{Effect of NO donors on the survival of bacteria}

In order to determine whether SNP and SIN-1 themselves have a direct effect on the viability of $E$. coli, $P$. vulgaris and $S$. Anatum in the absence of neutrophils, the bacteria were exposed to NO donors $(100$ and $1000 \mu \mathrm{M})$ for $1 \mathrm{~h}$. We observed that there was no difference in the survival of any of the tested bacteria after exposure to NO donors in compari-

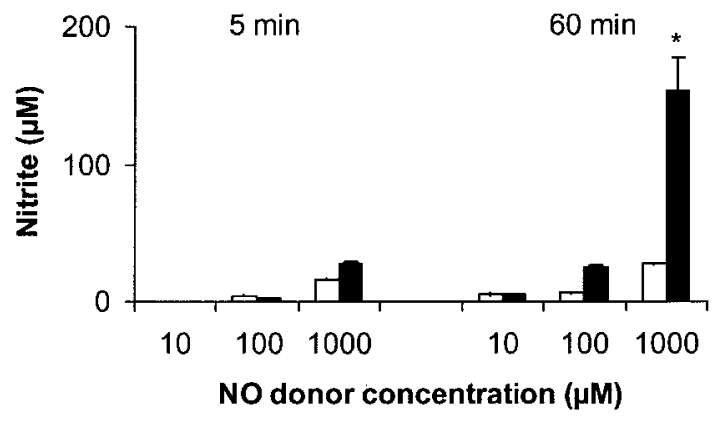

Fig. 1. Nitrite generation from NO donors in the presence of neutrophils and bacteria. SNP (open bars) or SIN-1 (filled bars) was added to a suspension of neutrophils $\left(5 \times 10^{5}\right)$ and bacteria $\left(5 \times 10^{6}\right)$ in RPMI 1640 medium for 5 or $60 \mathrm{~min}$ at $37^{\circ} \mathrm{C}$. The generation of nitrite from NO donors was measured using Griess reagent. Data are expressed as means $\pm S D$ of four independent experiments carried out with neutrophils from different individuals. Statistical significance: * , SNP versus $\mathrm{SIN}-1(P \leqslant 0.04)$.

son to untreated bacteria (data for E. coli shown in Fig. 2). Prolonged exposure of bacteria to NO donors ( $18 \mathrm{~h}$ ) had no significant effect on their survival (data not shown).

\section{Effect of NO donors on the ingestion of bacteria by neutrophils}

The data shown in Table 1 demonstrate that SNP and SIN-1 did not influence the degree of ingestion of different species of bacteria by neutrophils, independently of the concentration of NO donors used.

\section{Effect of NO donors on the bactericidal activity of neutrophils}

As shown in Fig. 3 and Table 2, in the absence of NO donors, the percentages of E. coli, P. vulgaris and S. Anatum cells killed by neutrophils were respectively $20-25,30-40$ and $0-1 \%$. We found that both SNP and SIN-1 enhanced the bactericidal

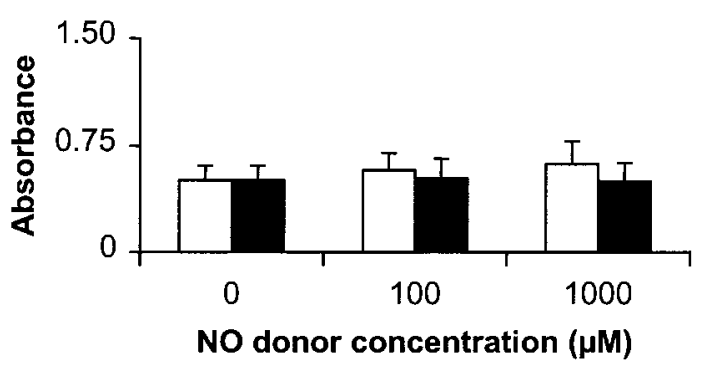

Fig. 2. Effect of NO donors on the survival of E. coli. SNP (open bars) or SIN-1 (filled bars) was added to RPMI 1640 culture medium in a 96 well plate for 5 min to initiate NO generation. Bacteria $\left(5 \times 10^{6}\right.$ cells per well) were then added to RPMI 1640 medium with or without NO donors. Reaction mixtures were incubated for $1 \mathrm{~h}$ at $37^{\circ} \mathrm{C}$. The viability of bacteria was determined by MTT assay. Data are expressed as means $\pm \mathrm{SD}$ of six independent experiments. $P$. vulgaris and $S$. Anatum gave similar results (not shown). 
Table 1. Effect of NO donors on the ingestion of bacteria by neutrophils

FITC-labelled bacteria $\left(1 \times 10^{7}\right)$ were incubated with neutrophils $\left(1 \times 10^{5}\right)$ for $1 \mathrm{~h}$ at $37^{\circ} \mathrm{C}$. Data are RFU expressed as means \pm SD of six independent experiments carried out with neutrophils from different individuals.

\begin{tabular}{|c|c|c|c|c|c|}
\hline \multirow[t]{2}{*}{ Bacterium } & \multirow{2}{*}{$\begin{array}{c}\text { Without NO } \\
\text { donors }\end{array}$} & \multicolumn{2}{|c|}{$\mathrm{SNP}(\boldsymbol{\mu M})$} & \multicolumn{2}{|c|}{ SIN-1 ( $\boldsymbol{\mu M})$} \\
\hline & & 100 & 1000 & 100 & 1000 \\
\hline E. coli & $0 \cdot 17 \pm 0 \cdot 01$ & $0 \cdot 17 \pm 0 \cdot 01$ & $0 \cdot 17 \pm 0 \cdot 01$ & $0 \cdot 16 \pm 0 \cdot 02$ & $0 \cdot 16 \pm 0 \cdot 01$ \\
\hline P. vulgaris & $0 \cdot 18 \pm 0 \cdot 02$ & $0 \cdot 17 \pm 0 \cdot 02$ & $0 \cdot 18 \pm 0 \cdot 02$ & $0 \cdot 18 \pm 0 \cdot 02$ & $0 \cdot 17 \pm 0 \cdot 02$ \\
\hline S. Anatum & $0 \cdot 16 \pm 0 \cdot 02$ & $0 \cdot 17 \pm 0 \cdot 02$ & $0 \cdot 17 \pm 0 \cdot 02$ & $0 \cdot 16 \pm 0 \cdot 01$ & $0 \cdot 16 \pm 0 \cdot 01$ \\
\hline
\end{tabular}

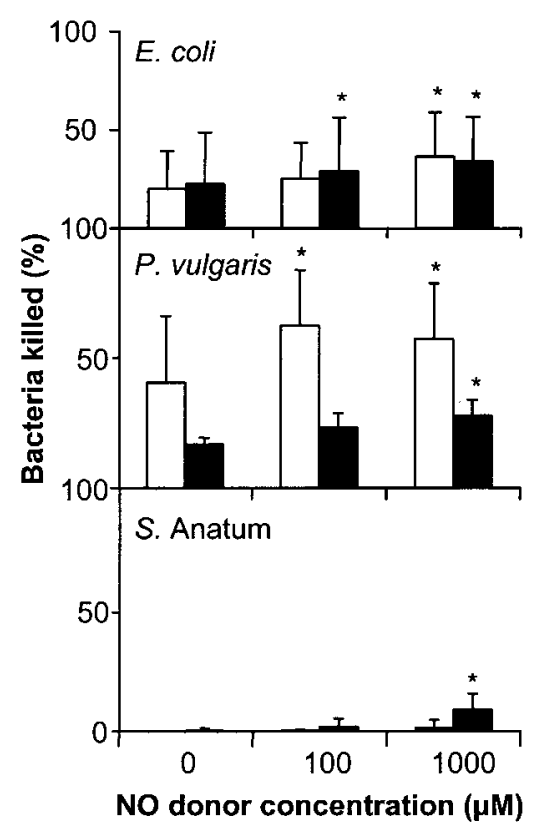

Fig. 3. Effect of $\mathrm{NO}$ donors on neutrophil-mediated bacteria killing. SNP (open bars) or SIN-1 (filled bars) was added to RPMI 1640 culture medium in the a 96 well plate for 5 min to initiate $\mathrm{NO}$ generation. Neutrophils $\left(5 \times 10^{5}\right.$ cells per well) and bacteria $\left(5 \times 10^{6}\right.$ cells per well) were then added to RPMI 1640 medium with or without NO donors. Reaction mixtures were incubated for $1 \mathrm{~h}$ at $37^{\circ} \mathrm{C}$. The viability of bacteria was determined by MTT assay. Data are expressed as means \pm SD of six independent experiments carried out with neutrophils from different individuals. Statistical significance: *, bacteria without NO donors versus bacteria with NO donors $(P \leqslant 0.04)$.

activity of neutrophils significantly, giving activities against $E$. coli of up to $30-40 \%, P$. vulgaris up to $60-70 \%$ and S. Anatum up to $10-15 \%$, as determined with the MTT and c.f.u. assays. However, the bacteria differed in their susceptibility to NO donor-mediated killing by neutrophils. SNP enhanced the bactericidal activity of neutrophils against $P$. vulgaris at concentrations of 100 and $1000 \mu \mathrm{M}$ and against E. coli at $1000 \mu \mathrm{M}$ only and had no effect on killing of S. Anatum. SIN-1 induced neutrophils to kill $P$. vulgaris and $S$. Anatum at $1000 \mu \mathrm{M}$ and to kill E. coli at 100 and $1000 \mu \mathrm{M}$ (Fig. 3).
Table 2. Effect of NO donors on neutrophil-mediated killing of bacteria

SNP $(1000 \mu \mathrm{M})$ or SIN-1 $(1000 \mu \mathrm{M})$ was added to RPMI 1640 culture medium for $5 \mathrm{~min}$ to initiate NO generation. Neutrophils $\left(5 \times 10^{6}\right.$ cells) and bacteria $\left(5 \times 10^{7}\right.$ cells $)$ were then added to RPMI 1640 medium with or without NO donors and the reaction mixtures were incubated for $1 \mathrm{~h}$ at $37^{\circ} \mathrm{C}$. Viability of bacteria was determined by the c.f.u. assay. Data are representative of four independent experiments carried out with neutrophils from different individuals.

\begin{tabular}{|lcc|}
\hline Condition & c.f.u. $\left(\times \mathbf{1 0}^{\mathbf{- 6}}\right)$ & Bacteria killed $(\%)$ \\
\hline E. coli & & \\
No NO donor & 10 & 20 \\
SNP & $9 \cdot 2$ & 28 \\
SIN-1 & $8 \cdot 5$ & 35 \\
P. vulgaris & & \\
No NO donor & 15 & 38 \\
SNP & $6 \cdot 9$ & 73 \\
SIN-1 & 10 & 58 \\
S. Anatum & & \\
No NO donor & 35 & 0 \\
SNP & 34 & 0 \\
SIN-1 & 30 & 15 \\
\hline
\end{tabular}

For further analysis of the mechanisms by which NO donors enhanced the bactericidal activity of neutrophils, we eliminated oxygen agents from the reaction mixture by adding SOD and CAT as scavengers of $\mathrm{O}_{2}^{-}$and $\mathrm{H}_{2} \mathrm{O}_{2}$, respectively. As demonstrated in Fig. 4, the addition of CAT did not affect NO donor-mediated bactericidal activity of neutrophils. The addition of SOD reduced the killing of E. coli and S. Anatum butnot . vulgarisbySNP-andSIN-1-treatedneutrophils.CAT and SOD had no significant effect on the bactericidal activity of neutrophils in the absence of NO donors (data not shown).

\section{Effect of SNP and SIN-1 on ROS production by neutrophils}

SNP and SIN-1 did not stimulate ROS production by neutrophils, as assayed by the CL method. CL values (in RLU) were as follows: untreated neutrophils, 9.8 $\pm 3 \cdot 4$; 


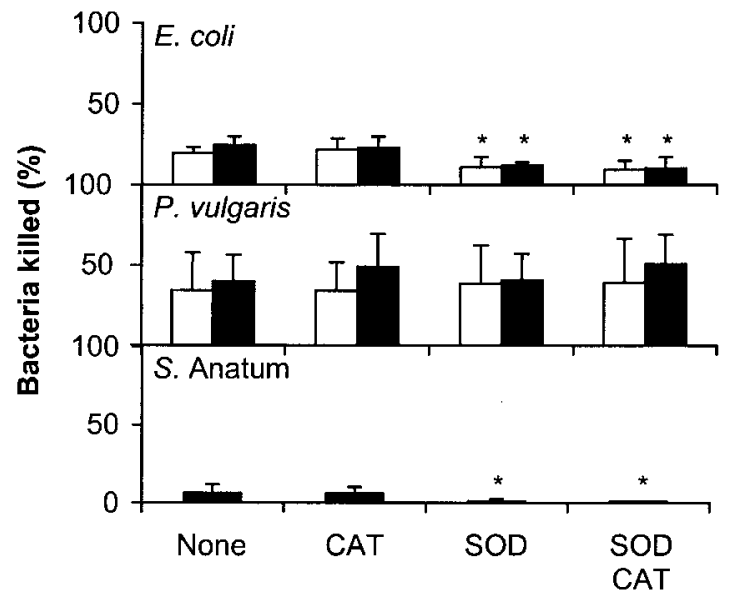

Fig. 4. Combined effect of NO donors and SOD and/or CAT on the bactericidal activity of neutrophils. SNP (open bars) or SIN-1 (filled bars) was added to RPMI 1640 culture medium in a 96 well plate for $5 \mathrm{~min}$ to initiate NO generation. Neutrophils $\left(5 \times 10^{5}\right.$ cells per well), bacteria $\left(5 \times 10^{6}\right.$ cells per well) and/or CAT $\left(1000 \mathrm{U} \mathrm{ml}^{-1}\right)$ and/or $\operatorname{SOD}\left(100 \mathrm{U} \mathrm{ml}^{-1}\right)$ as indicated were added to RPMI 1640 medium with or without NO donors. None, neither CAT nor SOD added. Reaction mixtures were incubated for $1 \mathrm{~h}$ at $37^{\circ} \mathrm{C}$. Data are expressed as means \pm SD of six independent experiments carried out with neutrophils from different individuals. Statistical significance: * , bacteria with NO donors versus bacteria with NO donors and SOD $(P \leqslant 0.05)$.

neutrophils $+100 \mu \mathrm{M}$ SIN-1, $7 \cdot 7 \pm 2 \cdot 8$; neutrophils +1000 $\mu \mathrm{M}$ SNP, 9.5 $\pm 1 \cdot 7$; neutrophils $+100 \mu \mathrm{M}$ SIN-1, $8 \cdot 3 \pm 3 \cdot 4$; neutrophils $+1000 \mu \mathrm{M}$ SIN-1, $7 \cdot 3 \pm 1 \cdot 2 ;$ neutrophils + PMA (positive control), $230 \cdot 4 \pm 42 \cdot 5(n=6)$.

\section{DISCUSSION}

Recognition of the role of $\mathrm{NO}$ donor compounds as antimicrobial agents and in other aspects of non-specific immunity is important with regard to their therapeutic usefulness. We found here that neither SNP nor SIN-1 alone showed a direct effect on the viability and survival of E. coli, $P$. vulgaris or S. Anatum in vitro (Fig. 2), although they were able to generate NO in the cell-free system. Similarly, other investigators have suggested that NO itself does not possess bactericidal activity for Salmonella species (De Groote et al., 1995) or E. coli (Pacelli et al., 1995). Although some authors have demonstrated that SIN-1 reduced the viability of Salmonella typhimurium (De Groote et al., 1995) or E. coli (Brunelli et al., 1995), this activity depended on the experimental conditions. It was shown that spontaneous decomposition of SIN-1 leads to the generation of equimolar quantities of $\mathrm{NO}$ and $\mathrm{O}_{2}^{-}$, which interact almost instantly to produce $\mathrm{ONOO}^{-}$(Yamamoto \& Bing, 2000), which is considered a bactericidal agent (Fang, 1997). However, the formation of $\mathrm{ONOO}^{-}$during decomposition of SIN-1 depends strongly on the oxygen concentration in the reaction mixture and, under anaerobic conditions, SIN-1 did not show bactericidal activity (De Groote et al., 1995; Brunelli et al., 1995; Doulias et al., 2001).
The participation of endogenously produced $\mathrm{NO}$ in the bactericidal activity of neutrophils has been studied (Malawista et al., 1992; Fierro et al., 1996), while the contribution of exogenously administered NO donor compounds to the killing of bacteria by neutrophils has not been studied intensively. It is well known that human neutrophils appear to produce very little (Larfars \& Gyllenhammar, 1998) or no (Yan et al., 1994) NO and, for some authors, the contribution of NO to the bactericidal activity of neutrophils is still uncertain (De Groote \& Fang, 1995). It should be pointed out that NO produced by other cells (endothelial and epithelial cells and macrophages) (Clancy et al., 1998) or administered as a drug (Feelisch, 1991; Janero, 2000) may participate in the formation of RNIs in neutrophils and/or extracellularly. The possible contribution of nitrovasodilators to the antimicrobial defence of the host has been emphasized since it was noticed that molsidomine-pretreated rodents showed reduced mortality in response to endotoxin (Cochran et al., 1999; Kumins et al., 1997).

In this study, we found that the bactericidal activity of $\mathrm{NO}$ donor-treated neutrophils was dependent on the species of microbe. SIN-1 significantly enhanced the antibacterial activity of neutrophils against all species of bacteria tested, while SNP potentiated the bactericidal activity of neutrophils against E. coli and P. vulgaris only. Additionally, E. coli was the most sensitive species to SIN-1-mediated killing, while $P$. vulgaris was most sensitive to SNP-mediated killing by neutrophils (Fig. 3). Our results confirm earlier observations of other investigators (Forslund \& Sundqvist, 1995a, b) that SNP and SIN-1 do not stimulate neutrophils to generate ROS. This suggests that NO donors do not enhance neutrophil bactericidal activity mediated by $\mathrm{O}_{2}^{-}$. On the basis of the experiments with the addition of SOD, we can assume that, when $\mathrm{O}_{2}^{-}$was scavenged from the reaction mixture, SNP and SIN-1 showed weaker ability to contribute to neutrophilmediated killing of E. coli and S. Anatum but not P. vulgaris (Fig. 4). It is possible that peroxynitrite, formed when NO (generated from donors) combines with $\mathrm{O}_{2}^{-}$derived from bacteria-phagocytosed neutrophils, participates in the elimination of E. coli and S. Anatum but not P. vulgaris. It should be noted that other nitrogen derivatives, such as $\mathrm{ONOOH}$, $\mathrm{NO}_{2} \mathrm{Cl}$ and $\mathrm{NO}_{2}$, which cause nitration and chlorination of tyrosine residues in bacteria, can also contribute to the bactericidal activity of neutrophils (Bogdan et al., 2000; Squadrito \& Pryor, 1998; Eiserich et al., 1998). We can assume that the participation of RNIs in killing of bacteria by neutrophils is dependent on the species of bacteria tested. It was suggested earlier that the main activity of RNIs is restricted to intracellular pathogens (e.g. Mycobacterium bovis, Leishmania major) (Miller \& Britigan, 1997). However, it has been noticed that E. coli (Pacelli et al., 1995) and Salmonella species (De Groote et al., 1995) are also targets for RNIs.

We found that the degree of ingestion of bacteria by neutrophils in vitro was independent of the presence of NO donors (Table 1). In contrast, Forslund \& Sundqvist (1997) have shown that an NO-releasing substance such as GEA-5171 decreased the phagocytosis of yeast particles by neutrophils. 
Our results show that NO donors are involved in the bactericidal activity of human neutrophils in vitro. We conclude that exogenously administered SNP and SIN-1 demonstrate varied effects on neutrophil function associated with the elimination of extracellular and facultatively intracellular bacteria. They do not have any effect on the process of bacterial ingestion, but they enhance the process of bacterial killing by neutrophils. The mechanisms of potentiated bacterial killing by SNP- and SIN-1-treated neutrophils are not clear. We assume that NO released from SNP and SIN-1 and its derivatives formed in the course of the interaction between neutrophils and bacteria are responsible for the enhancement of neutrophil antibacterial activity.

\section{ACKNOWLEDGEMENTS}

This research was supported by grant 4 P05A 03418 from the State Committee for Scientific Research (KBN), Poland.

\section{REFERENCES}

Armstrong, R. (2001). The physiological role and pharmacological potential of nitric oxide in neutrophil activation. Int Immunopharmacol 1, 1501-1512.

Babior, B. M. (1999). NADPH oxidase: an update. Blood 93, 1464-1476.

Bogdan, C., Röllinghoff, M. \& Diefenbach, A. (2000). Reactive oxygen and reactive nitrogen intermediates in innate and specific immunity. Curr Opin Immunol 12, 64-76.

Brunelli, L., Crow, J. P. \& Beckman, J. S. (1995). The comparative toxicity of nitric oxide and peroxynitrite to Escherichia coli. Arch Biochem Biophys 316, 327-334.

Chmiela, M., Wadstrom, T., Folkesson, H., Planeta Malecka, I., Czkwianianc, E., Rechcinski, T. \& Rudnicka, W. (1998). Anti-Lewis X antibody and Lewis X-anti-Lewis X immune complexes in Helicobacter pylori infection. Immunol Lett 61, 119-125.

Clancy, R. M., Amin, A. R. \& Abramson, S. B. (1998). The role of nitric oxide in inflammation and immunity. Arthritis Rheum 41, 1141-1151.

Cochran, J. B., Genovese, F., Ogura, S., Teti, G. \& Cook, J. A. (1999). Effect of nitric oxide donors and nitric oxide synthase inhibitors in neonatal rat endotoxic shock. Biochem Pharmacol 58, 687-691.

Dahlgren, C. \& Karlsson, A. (1999). Respiratory burst in human neutrophils. J Immunol Methods 232, 3-14.

De Groote, M. A. \& Fang, F. C. (1995). NO inhibitions: antimicrobial properties of nitric oxide. Clin Infect Dis 21 (Suppl. 2), S162-S165.

De Groote, M. A., Granger, D., Xu, Y., Campbell, G., Prince, R. \& Fang, F. C. (1995). Genetic and redox determinants of nitric oxide cytotoxicity in a Salmonella typhimurium model. Proc Natl Acad Sci U S A 92, 6399-6403.

Doulias, P. T., Barbouti, A., Galaris, D. \& Ischiropoulos, H. (2001). SIN1 -induced DNA damage in isolated human peripheral blood lymphocytes as assessed by single cell gel electrophoresis (comet assay). Free Radic Biol Med 30, 679-685.

Eiserich, J. P., Hristova, M., Cross, C. E., Jones, A. D., Freeman, B. A., Halliwell, B. \& van der Vliet, A. (1998). Formation of nitric oxidederived inflammatory oxidants by myeloperoxidase in neutrophils. Nature 391, 393-397.

Fang, F. C. (1997). Mechanisms of nitric oxide-related antimicrobial activity. J Clin Invest 99, 2818-2825.

Feelisch, M. J. (1991). The biochemical pathways of nitric oxide formation from nitrovasodilators: appropriate choice of exogenous $\mathrm{NO}$ donors and aspects of preparation and handling of aqueous solutions. J Cardiovasc Pharmacol 17 (Suppl. 3), S25-S33.

Fierro, I. M., Barja-Fidalgo, C., Cunha, F. Q. \& Ferreira, S. H. (1996). The involvement of nitric oxide in the anti-Candida albicans activity of rat neutrophils. Immunology 89, 295-300.

Forslund, T. \& Sundqvist, T. (1995a). Nitric oxide regulates the chemiluminescencefrom stimulated humanneutrophils. APMIS 103, 813-817.

Forslund, T. \& Sundqvist, T. (1995b). Nitric oxide reduces hydrogen peroxide production from human polymorphonuclear neutrophils. Eur J Clin Invest 25, 9-14.

Forslund, T. \& Sundqvist, T. (1997). Nitric oxide-releasing particles inhibit phagocytosis in human neutrophils. Biochem Biophys Res Commun 233, 492-495.

Green, L. C., Wagner, D. A., Glogowski, J., Skipper, P. L., Wishnok, J. S. \& Tannenbaum, S. R. (1982). Analysis of nitrate, nitrite, and $\left[{ }^{15} \mathrm{~N}\right]$ nitrate in biological fluids. Anal Biochem 126, 131-138.

Janero, D. R. (2000). Nitric oxide (NO)-related pharmaceuticals: contemporary approaches to therapeutic NO modulation. Free Radic Biol Med 28, 1495-1506.

Jones, R. D., Hancock, J. T. \& Morice, A. H. (2000). NADPH oxidase: a universal oxygen sensor? Free Radic Biol Med 29, 416-424.

Kumins, N. H., Hunt, J., Gamelli, R. L. \& Filkins, J. P. (1997). Molsidomine increases endotoxic survival and decreases cytokine production. Shock 7, 200-205.

Larfars, G. \& Gyllenhammar, H. (1998). Stimulus-dependent transduction mechanisms for nitric oxide release in human polymorphonuclear neutrophil leukocytes. J Lab Clin Med 132, 54-60.

Malawista, S. E., Montgomery, R. R. \& van Blaricom, G. (1992), Evidence for reactive nitrogen intermediates in killing of staphylococci by human neutrophil cytoplasts. A new microbicidal pathway for polymorphonuclear leukocytes. J Clin Invest 90, 631-636.

Miller, R. A. \& Britigan, B. E. (1997). Role of oxidants in microbial pathophysiology. Clin Microbiol Rev 10, 1-18.

Pacelli, R., Wink, D. A., Cook, J. A., Krishna, M. C., DeGraff, W., Friedman, N., Tsokos, M., Samuni, A. \& Mitchell, J. B. (1995). Nitric oxide potentiates hydrogen peroxide-induced killing of Escherichia coli. J Exp Med 182, 1469-1479.

Saran, M., Beck-Speier, I., Fellerhoff, B. \& Bauer, G. (1999). Phagocytic killing of microorganisms by radical processes: consequences of the reaction of hydroxyl radicals with chloride yielding chlorine atoms. Free Radic Biol Med 26, 482-490.

Squadrito, G. L. \& Pryor, W. A. (1998). Oxidative chemistry of nitric oxide: the role of superoxide, peroxynitrite, and carbon dioxide. Free Radic Biol Med 25, 392-403.

Stevens, M. G. \& Olsen, S. C. (1993). Comparative analysis of using MTT and XTT in colorimetric assays for quantitating bovine neutrophil bactericidal activity. J Immunol Methods 157, 225-231.

Umeki, S. (1994). Activation factors of neutrophil NADPH oxidase complex. Life Sci 55, 1-13.

Verhoef, J. \& Visser, M. R. (1993). Neutrophil phagocytosis and killing: normal function and microbial evasion. In The Neutrophils, pp. 109137. Edited by J. S. Abramson \& J. G. Wheeler. Oxford, New York \& Tokyo: IRL Press.

Yamamoto, T. \& Bing, R. J. (2000). Nitric oxide donors. Proc Soc Exp Biol Med 225, 200-206.

Yan, L., Vandivier, R. W., Suffredini, A. F. \& Danner, R. L. (1994). Human polymorphonuclear leukocytes lack detectable nitric oxide synthase activity. J Immunol 153, 1825-1834.

Zhu, L., Gunn, C. \& Beckman, J. S. (1992). Bactericidal activity of peroxynitrite. Arch Biochem Biophys 298, 452-457. 